\title{
Synergetic effects of Docetaxel and ionizing radiation reduced cell viability on MCF-7 breast cancer cell
}

\author{
Ali Ebrahimi Fard ${ }^{1}$, M. B. Tavakoli ${ }^{*}$, Hossein Salehi ${ }^{2}$ and Hamid Emami ${ }^{3}$
}

\begin{abstract}
Background: In recent decades neoadjuvant therapies such as combined chemotherapy and radiotherapy have been introduced for cancer management. Compared with monotherapy modalities, neoadjuvant therapy is associated with greater effectiveness while having minor side effects. Docetaxel is a chemotherapy agent for breast cancer treatment which can blocks the cell cycle at the $G_{2} / M$ phase which has shown special sensitivity to the ionizing radiation and hence causes cell death. To the best of our knowledge, there are currently no reports that explore the synergistic effects of Docetaxel and ionizing radiation on MCF-7 cancer cell death.

Methods: We divided cells into four different groups; control, cells which got in touch with Docetaxel, cells that with exposure to radiotherapy and cells which were influenced with combination of Docetaxel and radiotherapy. In vitro cell viability tests were done at different concentration of Docetaxel and different dose of radiation for 24,48 and $72 \mathrm{~h}$ after the experiment.

Results: Results showed that the cytotoxicity was depending on the doses of radiation and Docetaxel. Radiation at 2 Gy dose was unable to produce significant effects neither in the radiation-only nor in the neoadjuvant therapy groups. However, the synergistic effects of neoadjuvant therapy were apparent at 4 and 6 Gy doses of radiation which could exert more significant cytotoxic effects on MCF-7 cells.

Conclusions: Study findings suggest that neoadjuvant therapy by using Docetaxel and 4 and 6 Gy ionizing radiation has synergistic effects on MCF-7 cell death and produces more significant results compared with monotherapy modalities.
\end{abstract}

Keywords: Breast cancer, Chemotherapy, Radiotherapy, Neoadjuvant therapy, MCF-7

\section{Background}

Breast cancer is the most prevalent type of cancer among women worldwide and is considered as a health dilemma in both developing and developed countries [1]. In these countries, it has been stated that the incidence and the prevalence of breast cancer are considerably [2].

Depending on type and stage, cancer is usually treated by surgery, chemotherapy, hormonal therapy, and radiotherapy. In recent years, neoadjuvant therapy (such as surgery and radiotherapy or chemotherapy and radiotherapy) has been widely used for cancer treatment. The definition

\footnotetext{
*Correspondence: mbtavakoli@mui.ac.ir

${ }^{1}$ Medical Physics and Medical Engineering Department, School of Medicine,

Isfahan University of Medical Sciences, Isfahan 8175, Iran

Full list of author information is available at the end of the article
}

of neoadjuvant therapy is: treatment given as a first step to shrink a tumor before the main treatment, which is surgery or radiation therapy. Examples of neoadjuvant therapy include chemotherapy, radiation therapy, and hormone therapy [3].

In this regard, one of the innovative neoadjuvant therapies is the combination of Docetaxel chemotherapy agent with radiotherapy.

Microtubules are protein polymers which are responsible for differences in the shapes and the movements of the cell cycles [4]. The main component of the microtubules is tubulin polymer which is a protein two dissimilar subunits; $\alpha$ and $\beta$. The $\alpha$ and $\beta$ subunits bind together and form dimmers. Dimmers, in turn, are the constituent parts of microtubules (that are in turn the 
constituent parts of microtubules) [5]. Microtubules play a critical role in metotic cell division. Accordingly, drugs which can impede the movements and activities of microtubules are used for inhibiting cell division and thereby, treating malignancies such as metastatic breast cancer [6]. Taxaneanti-cancer agents such as Docetaxel and Paclitaxel $\left(\mathrm{Taxol}^{\circ}\right)$ are anti-cancer drug which exerts their anti-cancer effects through intracellular damaging [7]. They disturb the balance between the polymerization and depolymerization of tubulin dimmers through inhibiting either the polymerization of tubulin dimmers or the depolymerization of already formed dimmers [8]. The first mechanism, i.e. the inhibition of tubulin dimmers polymerization, is dominant. In other words, Taxane agents mainly stabilize tubulin dimmers against polymerization [9] and hence, either prevent the formation of microtubule polymers or result in the formation of abnormal non-functional microtubules [10]. Clusters of abnormal microtubules in tumor cells prevent the normal separation of chromosomes and therebyblock the cell cycle between the G2 and M phases [11]. The final outcome is the prevention of cell division. In an experimental study, Hernández-Vargas et al. found that Docetaxel blocks the growth of MCF-7 cells in the $\mathrm{G}_{2} \mathrm{M}$ phase [12]. Meanwhile, Taxane agents also decrease the amount of active $\beta$-tubules through binding to free $\beta$-tubules. When the amount of active B-tubules is decreased, the production of tubulin dimmers is consequently inhibited [9].

Docetaxel is a semi-synthetic antagonist which is extracted from Taxusbrevifolia [13]. The differences between Docetaxel and Paclitaxel are in their chemical structures. Docetaxel has a hydroxyl functional group on carbon 10 while Paclitaxel includes an acetate ester in its structure [9]. The hydroxyl functional group makes Docetaxel more water-soluble than Paclitaxel [14]. Docetaxel is approved by the Food and Drug Administration in 1996 as an anti-cancer agent [15]. Previous studies have shown that, in in vitro condition, it has radiosensitizing effects on colon, lung and neck of the cancer cells [16-20].

Some kinds of cancerous tumors are treated by using $\mathrm{x}$ - and gamma-rays radiation. Both of these two radiation have ionizing effects and they transfer certain amounts of energy to the irradiated cells [21]. The transferred energy has significant role in damaging cellular DNA and thereby, killing cancer cells. There are two types of effect for ionization radiation on cells: direct effect and indirect effect. The accepted direct effects of ionization radiation are: cell death, chromosomal aberrations, DNA damage and mutagenesis. From indirect damage through reactive oxygen species produced by radiolysis of water, and these biological effects were attributed to irreparable or misrepaired DNA damage in cells directly hit by radiation. Given the differences in their structures, different cells have varying levels of radiosensitivity. Generally, cells that have more proliferation are more sensitive to ionizing radiation [22].

Previous studies have shown the alone effects of chemotherapy and radiotherapy on cells [23, 24]. However, the effects of neoadjuvant therapy, using radiation and Docetaxel, as a chemotherapy agent, have not been fully assessed. Preliminary results of previous studies, showed that combined radiotherapy and chemotherapy exerted synergistic effects on both animal and human cells, It should be noted that, this effects were not limited to SQ20B, head and neck ZMK-1 and CASKI cancer cells, cancer cells of the lung, as well as V79 and RGM1 cells. All these studies reported that neoadjuvant therapy significantly increases cell death rate [25-29]. Kars et al. studied the radioresistance in drug resistant human MCF-7 breast cancer cells. They reported that some of the multi-drug has resistance effect on cancer cells that lead to become radioresistant [30].

However, to the best of our knowledge, the effects of combined radiotherapy and chemotherapy using Docetaxel and ionizing radiation on MCF-7 cells have not yet been evaluated. The aim of the study was to investigate the in vitro synergetic effects of Docetaxel chemotherapy and ionizing radiation on MCF-7 breast cancer cell death.

\section{Methods}

\section{Cell culture}

MCF-7 breast cancer cells (purchased from Pasteur Institute of Iran, Tehran, Iran) were cultured in Dulbecco's Modified Eagle Medium (DMEM; Bioldia Company) which contained 10\% fetal bovine serum (Gibco Company) and $1 \%$ streptomycin/ penicillin (Bioldia Company). Cultured cells were incubated at $37{ }^{\circ} \mathrm{C}$ in an atmosphere of $5 \% \mathrm{CO}_{2}$ for $24 \mathrm{~h}$. For cytotoxicity testing, cells were seeded on 96-well plates at a concentration of 5000 cells per well in $100 \mu \mathrm{l}$ of medium for each cell line. Plates were incubated for $24 \mathrm{~h}$.

Cells were allocated to either the control, Docetaxel-only, radiotherapy-only, or combined Docetaxel-radiotherapy groups. In the Docetaxel-only group, 1, 5, 25, 50, 75, 100, and 200 micromolar $(\mu \mathrm{M})$ doses of Docetaxel (Actavis Pharmaceutical Company) was prepared. Then, each dose of Docetaxel was added to a well containing 5000 cells. After five hours, Docetaxel containing medium was removed and fresh medium was added to each well. In the radiotherapy-only group, radiotherapy was performed at three doses of 2, 4, and 6 Gy by using a Cobalt-60 machine (Phonix) at Seyedoshohad Hospital, 
Isfahan, Iran. Cells in the combined Docetaxel-radiotherapy group were initially treated for five hours with different concentration $(1,5,25,50,75,100$, and $200 \mu \mathrm{M})$ of Docetaxel and then were exposed to three doses of 2, 4, and 6 Gy of radiation by using the Cobalt- 60 machine. Each sample was seeded in three separate wells.

\section{MTT assay}

This method is based on the reduction of multi 3-(4, 5dimethylthiazol-2-yl)-2, 5-diphenyltetrazoliumbromide (MTT). After 24, 48 and $72 \mathrm{~h}$ of incubation, the medium was removed, cells were washed two times by phosphate buffer saline (PBS), then $100 \mu \mathrm{l}$ pure medium culture was added to each well and $10 \mu \mathrm{M}$ of MTT solution (at a concentration of $5 \mathrm{mg} \mathrm{ml}^{-1}$ in $\operatorname{PBS}(1 \times)$ ) was added to them. Wells were again incubated at $37.0{ }^{\circ} \mathrm{C}$ for $4 \mathrm{~h}$. Thereafter, the supernatants of the wells were removed and $100 \mu \mathrm{L}$ of dimethyl sulfoxide (DMSO) was added to each of them to solubilize formazan crystals. The plate was incubated for $1 \mathrm{~h}$ again and finally, the absorbance of each well was read at $570 \mathrm{~nm}$ using an ELISA reader (Bio-rad. USA). Cell viability rate was calculated by using the following formula,

$$
\text { Viable cells } \%=\frac{\text { Optical density of treated samples }}{\text { Optical density of control samples }} \times 100
$$

\section{Isobologram analysis}

The isobologram analysis was used to find synergism or additive or antagonism effects, when Docetaxel and radiation were combined.

It was done by using combination index (CI) method of Chou-Talalay [31, 32].

The combination index $(\mathrm{CI})$ was calculated by the formula:

$$
C I=(d 1 / D x 1)+(d 2 / D x 2)
$$

Where $D x 1$ is the dose of agent 1 (radiation) required to produce $x$ percentage effect alone, and $d 1$ is the dose of agent 1 required to produce the same $x$ percentage effect in combination with $d 2 . D x 2$ is similarly the dose of agent 2 (Docetaxel) required to produce $x$ percentage effect alone, and $d 2$ is the dose of agent 2 required to produce the same $x$ percentage effect in combination with d1.The combined IC50 was determined for plotted as an isobologram and the CI values were interpreted as follows: <1.0, synergism; 1.0, additive; and >1.0, antagonism [33]. The $(D x 1)$ or $(D x 2)$ for docetaxel and radiation can be calculated from the medianeffect equation of Chou [34]:

$$
\mathrm{Dx}=\mathrm{Dm} \cdot[\mathrm{fa} / 1-\mathrm{fa}]^{1 / \mathrm{m}}
$$

where $f_{a}$ is the fraction affected and $D_{m}$ is the median effect concentration or dose (IC50) that is obtained from the antilog of the $\mathrm{X}$-intercept of the median effect plot, $\mathrm{X}$ $\log (D)$ versus $Y=\log \left[f_{a} /\left(1-f_{a}\right)\right]$ or $D_{m}=10^{-(y \text {-intercet }) / m}$, and $\mathrm{m}$ is the slope of the median effect plot [35].

The software program "Combosyn" (combosyn, Inc., USA) was used to perform this analysis and generate a CI-isobologram Graphical representation for combination effect with the $\mathrm{CI}$ on the $\mathrm{y}$-axis and the $\mathrm{fa}$ (fraction of effect affected i.e. the CI for a particular \% cell death e.g. 0.5 for $50 \%$ ) on the $\mathrm{x}$-axis.

\section{Data analysis}

The Statistical Package for Social Sciences (SPSS v. 22.0) was used for data analysis. As all the experiments had been repeated for three times, a mean was considered as the results of each experiment. Study groups were compared using the one-way analysis of variance test and the Tukey's post hoc test [ANOVA (Tukey)]. The significance level was set at $0.05(P<0.05)$.

\section{Results}

The results of MTT assay for 2 Gy radiation

The effects of Docetaxel chemotherapy and 2 Gy radiation on MCF-7 cell death at 24, $4872 \mathrm{~h}$ are shown in Fig. 1a-c. Figure 1a, shows cell viability rate at $24 \mathrm{~h}$. This figure depicts that Docetaxel-alone and the neoadjuvant therapy caused significantly higher MCF-7 cell death at 75,100 , and $200 \mu \mathrm{M}$ doses of Docetaxel compared with the control group. Moreover, the differences between the Docetaxel-only and the neoadjuvant therapy groups were not statistically significant $(P \geq 0.05)$, denoting that 2 Gy radiation in the neoadjuvant therapy group had no significant effect on cell death rate after $24 \mathrm{~h}$.

Figure $1 \mathrm{~b}$, shows the results of MTT assay at $48 \mathrm{~h}$. This figure indicates that the Docetaxel-only and the neoadjuvant therapy groups differed significantly from the control group at $25 \mu \mathrm{M}$ and larger doses of Docetaxel.

The results of MTT assay at $72 \mathrm{~h}$ are shown in Fig. 1c. This figure shows that, compared with the control group, both Docetaxel-only and neoadjuvant therapy treatments caused significantly higher MCF-7 cell death at all doses of Docetaxel except for the $1 \mu \mathrm{M}$ dose $(P<0.05)$. Moreover, the Docetaxel-only and the neoadjuvant therapy groups differed significantly from each other at 100 and $200 \mu \mathrm{M}$ doses of Docetaxel $(P<0.05)$. In the figures, we have considered the control group basis, so we consider the control group to $100 \%$ and all 

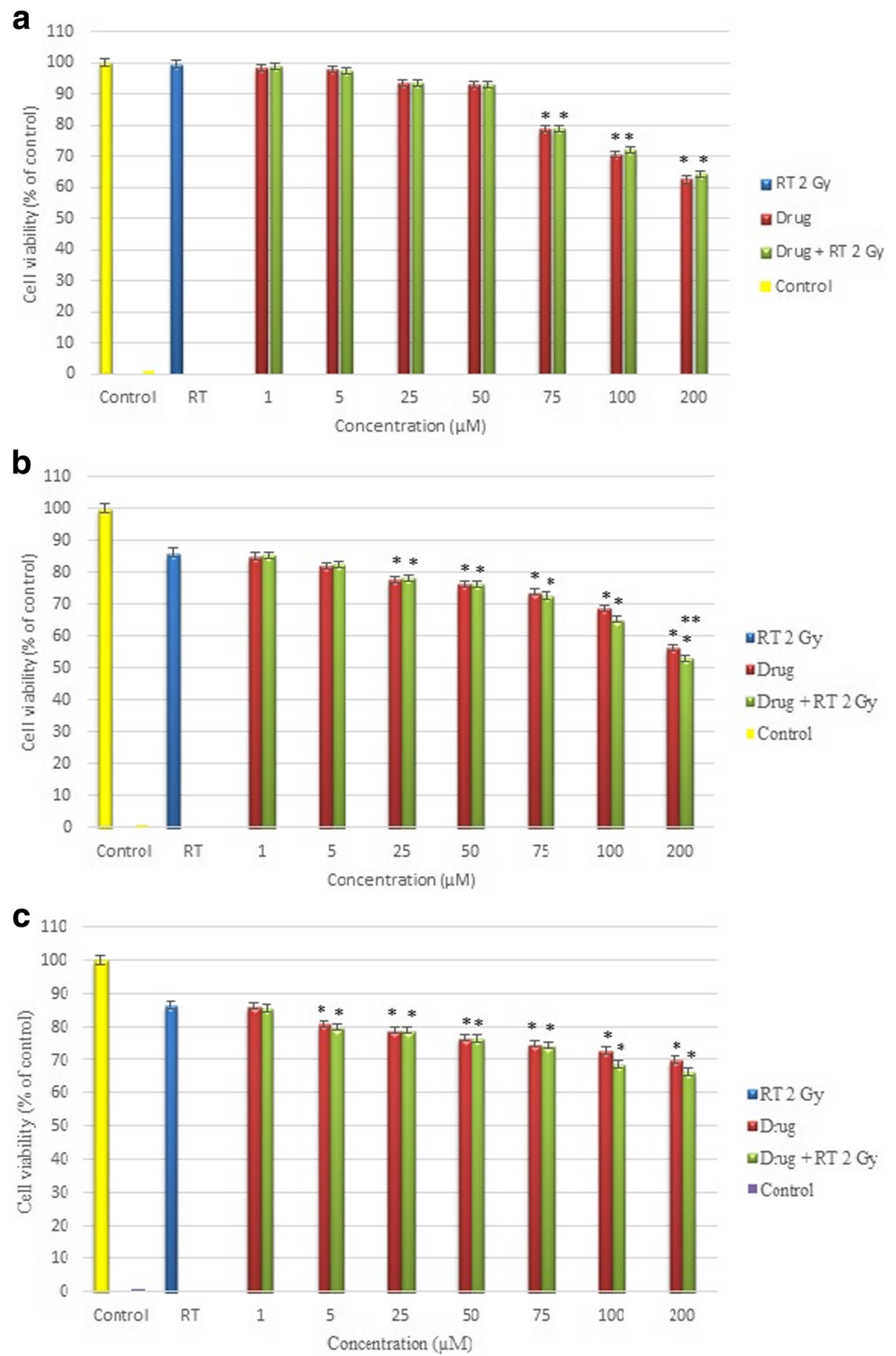

Fig. 1 a-c Cell viability of the cell line MCF-7 under the different concentration of Docetaxel and 2 Gy ionization radiation. a incubation time 24 h; b incubation time 48 h; (c) incubation time 72 h. (*: significantly different from the control group. $P<0.05,{ }^{* *}$ : significantly different from the control group. $P<0.01,{ }^{* * *}$ : significantly different from the control group. $P<0.001$ ) 
results normalized from it. Because cells in the control group did not have any treatment.

\section{The results of MTT assay for 4Gy radiation}

The results of MTT assay for 4 Gy radiation at $24 \mathrm{~h}$, $48 \mathrm{~h}$, and $72 \mathrm{~h}$ are depicted in Fig. 2a-c. Figure 2a shows the results for $24 \mathrm{~h}$. According to this figure, while the neoadjuvant therapy group differed significantly from the control group at all doses of Docetaxel $(P<0.05)$, the difference between the Docetaxel-only group and the control group was significant only at 75, 100, and $200 \mu \mathrm{M}$ doses of the drug. Moreover, the MCF-7 cell death rate in the Docetaxel-only group was significantly lower than the neoadjuvant therapy groups at all doses of Docetaxel $(P<0.05)$. On the other hand, the cell death rate caused by radiotherapy-only treatment was significantly higher than the control group and lower than the neoadjuvant therapy group.

Figure $2 \mathrm{~b}$ depicts the results of MTT assay for $4 \mathrm{~Gy}$ radiation at $48 \mathrm{~h}$. According to this figure, the pattern of pairwise differences among the study groups at $48 \mathrm{~h}$ is similar to that of $24 \mathrm{~h}$. However, there are two differences between these two time-points. Firstly, cell death rates at $48 \mathrm{~h}$ were significantly higher than that at $24 \mathrm{~h}$. Secondly, at $24 \mathrm{~h}$, the Docetaxel-only group differed significantly from the control group only at 75,100 , and $200 \mu \mathrm{M}$ doses of Docetaxel $(P<0.05)$. While at $48 \mathrm{~h}$, these two groups differed significantly from each other at all doses of the drugs except for the $1 \mu \mathrm{M}$ dose.

The results of MTT assay at $72 \mathrm{~h}$ for 4 Gy radiation are shown in Fig. 2c. The comparison of this figure with Fig. $2 \mathrm{~b}$ shows that the pattern of pairwise is similar among the study groups at $72 \mathrm{~h}$ and $48 \mathrm{~h}$. The only difference was that cell death rates at $72 \mathrm{~h}$ were significantly lower than $48 \mathrm{~h}$.

\section{The results of MTT assay for 6 Gy radiation}

The results of MTT assay for 6 Gy radiation are depicted in Fig. 3a-c. Figure 3a indicates the results of MTT assay for 6 Gy radiation at $24 \mathrm{~h}$. According to this figure, cell death rate in both the radiotherapy-only and neoadjuvant therapy groups was significantly higher than the control group. However, the differences between the control and the Docetaxel-only groups were significant at 75,100 , and $200 \mu \mathrm{M}$ doses of Docetaxel. On the other hand, cell death rate in the neoadjuvant therapy group was also higher than both the radiotherapy-only and the Docetaxel-only groups at all doses of Docetaxel.

The results of MTT assay for 6 Gy radiation at $48 \mathrm{~h}$ are indicated in Fig. 3b. Although, the pattern of pairwise differences among the study groups at this time-point was similar to that of $24 \mathrm{~h}$. There were two differences between these two time-points. Firstly, compared with $24 \mathrm{~h}$, cell death rates at $48 \mathrm{~h}$ were higher. As can be seen from
Fig. 3b, death rates at 75, 100, and $200 \mu \mathrm{M}$ doses of Docetaxel at $48 \mathrm{~h}$ were two times more than $24 \mathrm{~h}$. Secondly, at $24 \mathrm{~h}$ the Docetaxel-only and the control groups differed significantly from each other only at $75(P<0.05), 100$ $(P<0.05)$, and $200(P<0.05) \mu \mathrm{M}$ doses of Docetaxel, whereas, all the differences between these two groups at $48 \mathrm{~h}$ were statistically significant $(P<0.05)$ except for the $1 \mu \mathrm{M}$ dose of the drug $(P<0.05)$.

Figure 3c illustrates the results of MTT assay for $6 \mathrm{~Gy}$ radiation at $72 \mathrm{~h}$. According to this figure, the pattern of pairwise differences among the study groups at $72 \mathrm{~h}$ is the same as $48 \mathrm{~h}$, except for cell death rates which are significantly lower.

The effects of neoadjuvant therapy at 2, 4, and 6 Gy radiation at $24 \mathrm{~h}, 48 \mathrm{~h}$, and $72 \mathrm{~h}$ are depicted in Figs. 4a-c, 5, and 6 respectively. These three figures show that larger doses of chemotherapy and radiotherapy are associated with higher rates of cell death. The important point is the large distance between the line of 2 Gy radiation and the two remaining lines. Moreover, compared with $24 \mathrm{~h}$, the 4 Gy and the 6 Gy lines showed a downward and an upward displacement at $48 \mathrm{~h}$ and $72 \mathrm{~h}$, respectively.

\section{Combination of Docetaxel and radiation}

Docetaxel was cytotoxic in high concentration for MCF7 cell line. The IC50 concentration for Docetaxel alone almost was in the $200 \mu \mathrm{M}$ for $48 \mathrm{~h}$ incubation.

Cell line was relatively resistant to the cytotoxic effects of a single radiation exposure of 2 Gy. The results of combination effect of docetaxel and radiation in synergistic cytoxicity for MCF7 cells shown in Fig. 2b and c.

The IC50 values for the combination of radiation and Docetaxel fall below 1.0, indicating that the neoadjuvant therapy had the synergistic effect (Fig. 2b, (c)).

\section{Discussion}

Neoadjuvant therapy is an effective method for cancer treatment [36]. In some kinds of cancer, chemotherapy makes cancer cells more sensitive to radiotherapy and hence, radiotherapy mainly affects cancer cells rather than normal [37]. Previous studies have shown that, combined Docetaxel-radiotherapy treatment increases the treatment rate by $1.3-3.2[38,39]$.

In this research it was tried to study the in vitro synergetic effects of Docetaxel chemotherapy and ionizing radiation on MCF-7 breast cancer cell death. For this purpose, cells were allocated in different groups namely; control, Docetaxel-only, radiotherapy-only, and combined Docetaxel-radiotherapy and the synergetic effects of Docetaxel and ionizing radiation on cell death were evaluated.

Results revealed that at $24 \mathrm{~h}$ incubation, Docetaxel-only therapy as well as neoadjuvant therapy had no significant 

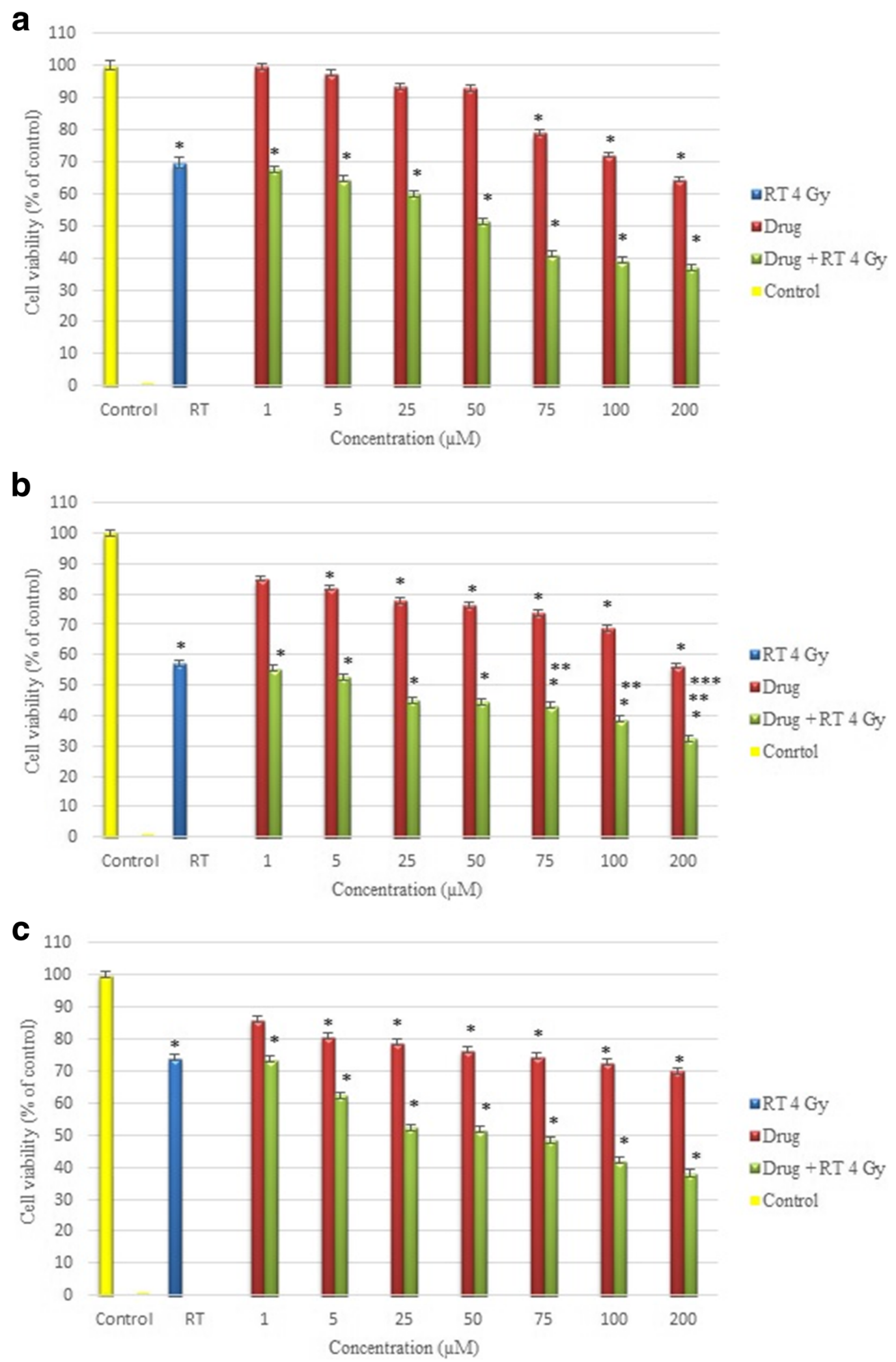

Fig. 2 a-c Cell viability of the cell line MCF-7 under the different concentration of Docetaxel and 4 Gy ionization radiation. a incubation time 24 h; $\mathbf{b}$ incubation time $48 \mathrm{~h}$; c incubation time 72 h. ( ${ }^{*}$ : significantly different from the control group. $P<0.05$, ${ }^{* *}$ : significantly different from the control group. $P<0.011^{* * *}$ : significantly different from the control group. $P<0.001$ ) 
a

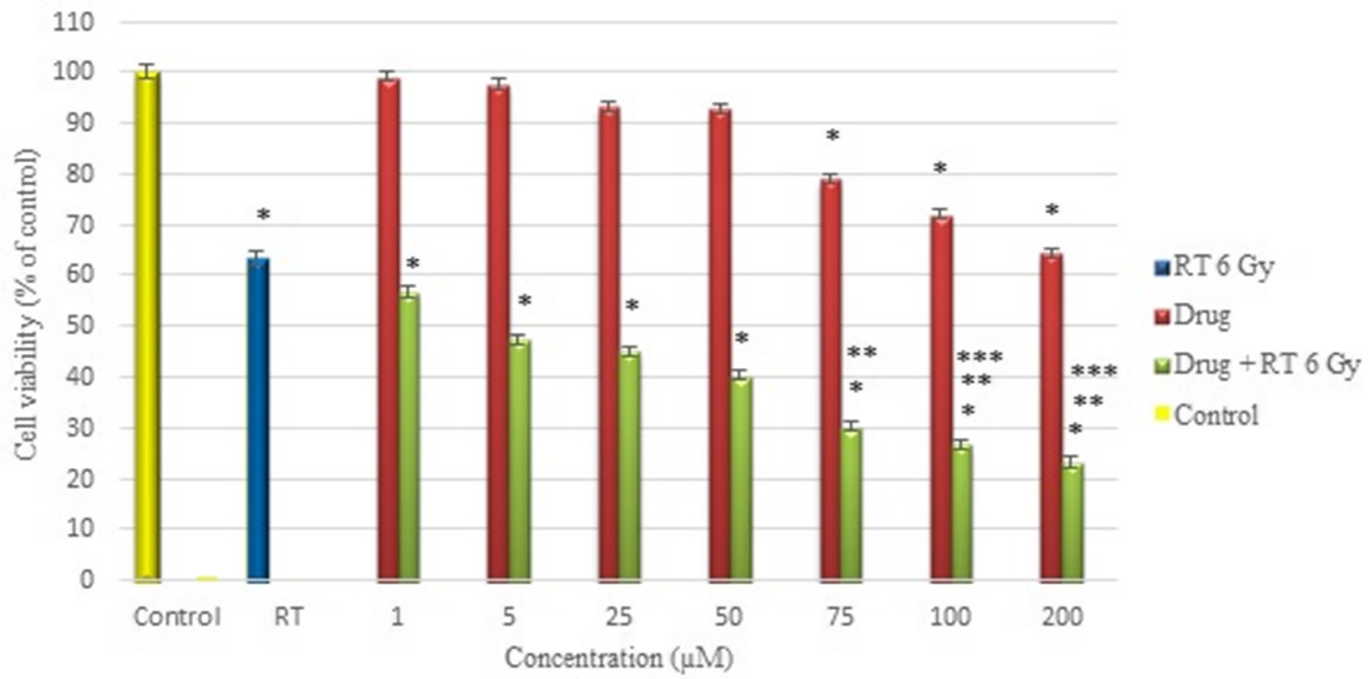

b
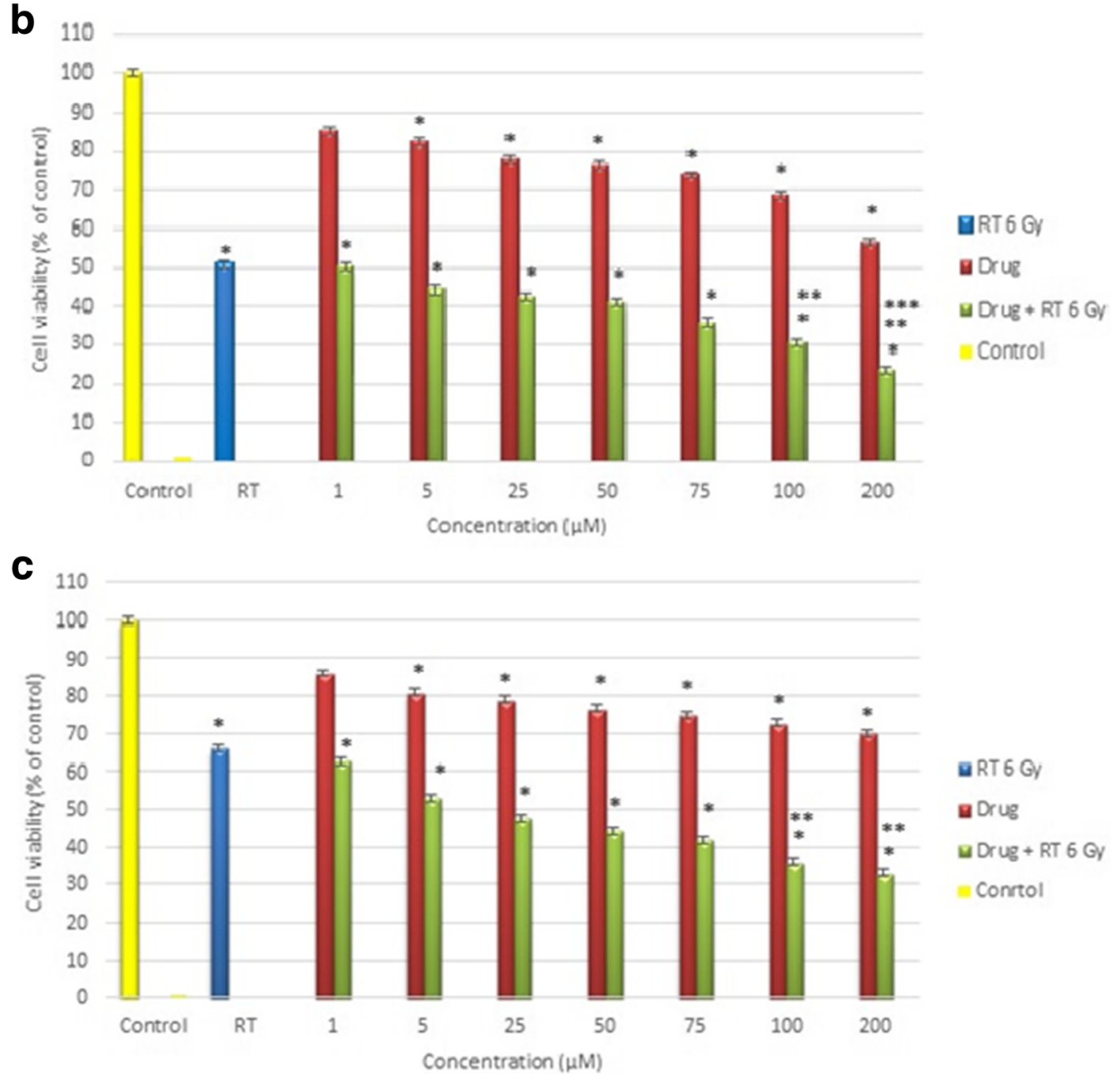

Fig. 3 a-c Cell viability of the cell line MCF-7 under the different concentration of Docetaxel and 6 Gy ionization radiation. a incubation time 24 h; $\mathbf{b}$ incubation time $48 \mathrm{~h}$; c incubation time 72 h. ( ${ }^{*}$ : significantly different from the control group. $P<0.05$, ${ }^{* *}$ : significantly different from the control group. $P<0.01,{ }^{* * *}$ : significantly different from the control group. $\left.P<0.001\right)$ 

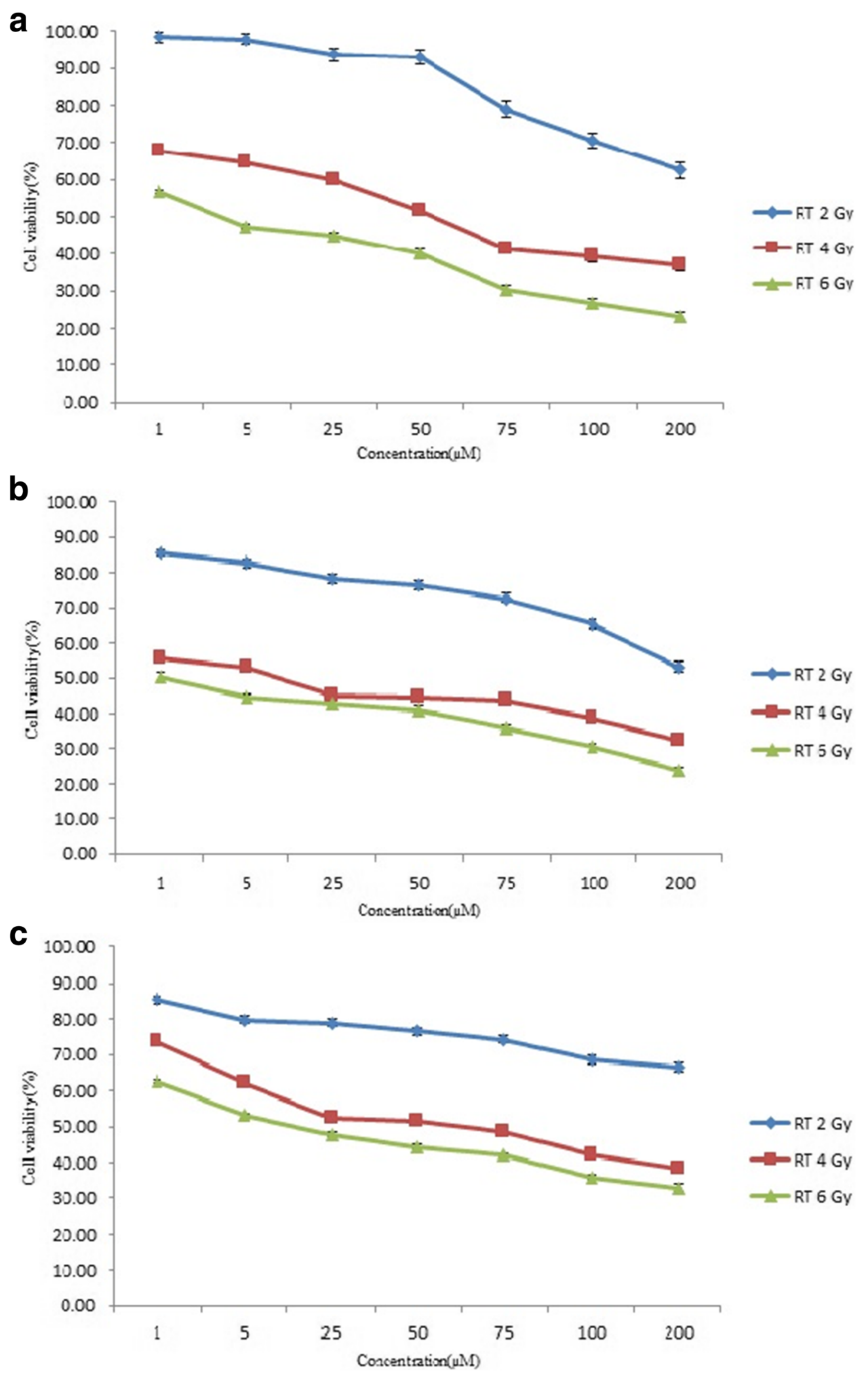

Fig. 4 a-c Cell viability of the cell line MCF-7 under the neoadjuvant therapy. a Different concentration of Docetaxel and doses of ionization radiation with incubation time $24 \mathrm{~h}$; $\mathbf{b}$ different concentration of Docetaxel and doses of ionization radiation with incubation time 48 h; c different concentration of Docetaxel and doses of ionization radiation with incubation time $72 \mathrm{~h}$ 


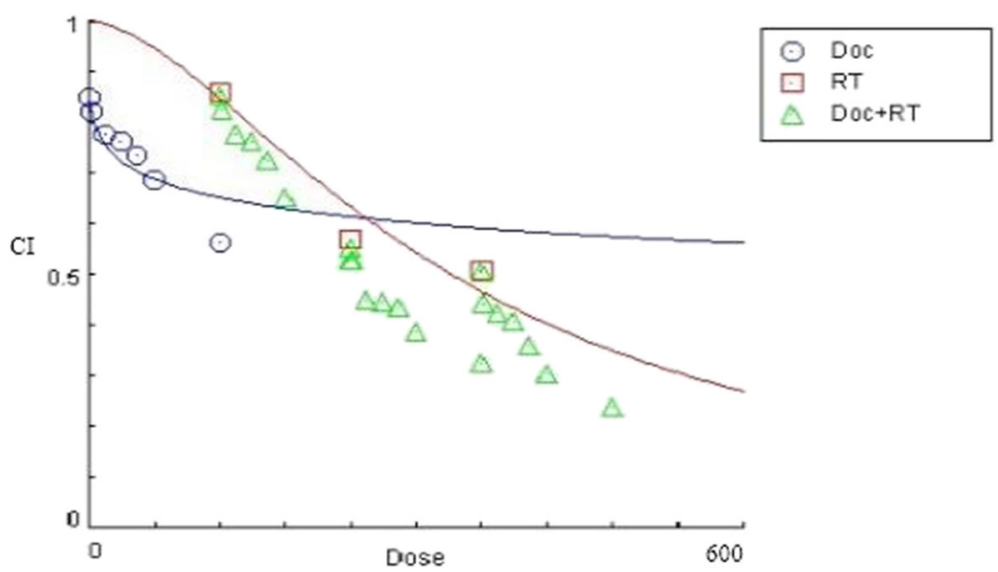

Fig. 5 The isobologram analysis have been used to find synergism or additive or antagonism effects, the combination index (Cl) for the cell treatment with Docetaxel (Doc) and Radiation (RT) for $48 \mathrm{~h} . \mathrm{Cl}<1.0$ clearly points to a synergistic effect

effects on cell death at $1,5,25$, and $50 \mu \mathrm{M}$ doses of Docetaxel (Fig. 1a). However, at $48 \mathrm{~h}, 25$ and $50 \mu \mathrm{M}$ doses of Docetaxel and at $72 \mathrm{~h}$ and $5 \mu \mathrm{M}$ dose also exerted significant effects on cell death in both the Docetaxel-only and the neoadjuvant therapy groups $(P<0.05)$. These findings indicated that cell death rate depends on both time and Docetaxel dose. Moreover, no significant difference was found between the control and the radiotherapy-only groups as well as between the Docetaxel-only and the neoadjuvant therapy groups, confirming that 2 Gy radiation has neither direct nor indirect effects on MCF-7 cell death rate. On the other hand, given the insignificant differences between the radiotherapy-only and the control groups at $48 \mathrm{~h}$ and $72 \mathrm{~h}$, higher cell death rates at lower doses of Docetaxel in both the Docetaxel-only and the neoadjuvant therapy groups can also be attributed to the effects of Docetaxel and time. The ineffectiveness of radiotherapy-only treatment at $48 \mathrm{~h}$ and $72 \mathrm{~h}$ is probably due to the insufficiency of the energy transferred from 2 Gy photons to cells for inflicting DNA damages and increasing cell death rate.

The findings of the study showed that when the dose of radiotherapy was increased to $4 \mathrm{~Gy}$, cell death rates both in the radiotherapy-only and the neoadjuvant therapy groups were significantly higher than the control and the Docetaxel-only groups. These findings denoted the effectiveness of 4 Gy radiation in cell death. Compared with 2 Gy dose, the amount of energy transferred to the cells at 4 Gy radiation was sufficient enough for causing cell death. Moreover, 4 Gy radiation might have caused the generation and the accumulation of free radicals $[19,40,41]$. On the other hand, since the differences between the Docetaxel-only and the neoadjuvant therapy groups were not significant at 2 Gy radiations, these two

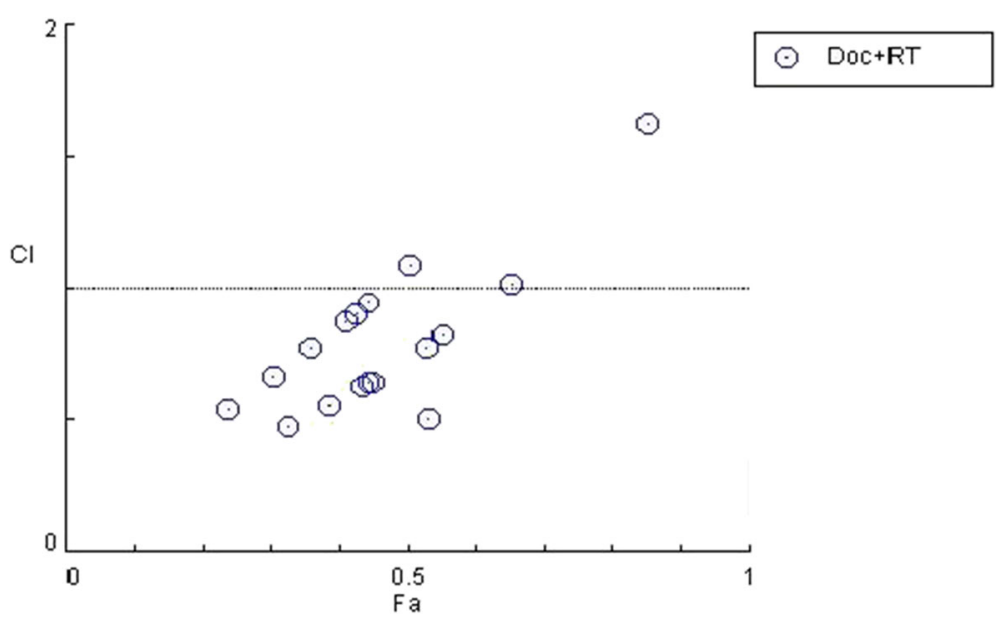

Fig. 6 The plot of the Combination Index (CI) VS. Fraction affected ( $\mathrm{Fa}$ ) for the cell line MCF-7 under the neoadjuvant therapy: Different concentration of Docetaxel and doses of ionization radiation 
groups significantly differed from each other when the dose of radiation was increased to $4 \mathrm{~Gy}$. This finding confirms the synergistic effects of neoadjuvant radiotherapy and Docetaxel chemotherapy.

Our results showed a synergictic effect on enhance growth inhibition on MCF7 cells when using the combination of Docetaxel and radiation compare with each agent alone. This effect shown clearly by attached CI $(<1.0)$ (Fig. 2b, (c)).

Ural et al. showed previously the synergistic effect of Zoledronic acid and radiation on MCF7 cells that reported was same with our study [33].

A surprising finding was lower cell death rates at $72 \mathrm{~h}$ compared with $48 \mathrm{~h}$. This finding can be due to the fact that some cells which had experienced minimal radiotherapy- and chemotherapy-induced damages were able to repair their damages and restart proliferation. Accordingly, the number of viable cells increased at $72 \mathrm{~h}$.

Study findings demonstrated that increasing the dose of radiation to 6 Gy caused more considerable cell damage and higher cell death compared with 4 Gy radiation. The reason is the sufficiency of the energy transferred to cells from 6 Gy photons as well as the radiosensitizing effects of Docetaxel. This finding shows the greater effectiveness of 6 Gy radiation in causing cell damage and death.

The limited effectiveness of 2 Gy radiation in causing cell death compared with 4 and 6 Gy radiations is shown in Fig. 4a-c. These figures illustrate the cell viability at 2 Gy radiation was significantly lower, compared to 4 , and 6 Gy radiation $(P<0.05)$. Moreover, it can be seen that larger doses of Docetaxel resulted in higher cell death rate. On the other hand, given the low Linear Energy Transfer (LET) of Cobalt-60 photons, the lines of these three figures are expected to have a plateau. However, none of these lines reached to a plateau. The cause is the radiosensitizing effects of Docetaxel even at its low doses. In a similar study conducted on (ESCC) cells, Tabuchi et al. (2011) reported a same [39]. Compared with Fig. 4a, the distance of line 2 Gy from 4 and 6 Gy lines is greater in Fig. 4b, confirming the stronger effects of 4 and 6 Gy radiation. However, this distance is shortened again in Fig. 4c. As mentioned before, this finding shows that after $24 \mathrm{~h}$, minimally-damaged cells have started repairing damages and continuing growth and proliferation.

Our findings revealed that compared with monotherapy, neoadjuvant therapy, particularly at high doses, is more effective in damaging and killing cancer cells. Pradier et al. (2001) and Kim et al. (2002) also reported the same finding $[28,30]$. However, the death rate in our study was different from these two studies, probably due to the differences in the types of the assessed cells, the doses of the administered anticancer agents, and the length of exposing cells to anticancer agents.

Moreover, treatment rate was calculated through dividing death rate in the neoadjuvant therapy group by death rate in the Docetaxel-only group. Accordingly, treatment rates of neoadjuvant therapy with 6 Gy radiation at $48 \mathrm{~h}$ for the $1,5,25,50,75,100$, and $200 \mu \mathrm{M}$ doses of Docetaxel were equal to $1.68,1.75,1.83,1.86$, $2.05,2.25$, and 2.36 (UNIT), respectively, showing that at 75,100 , and $200 \mu \mathrm{M}$ doses of Docetaxel, treatment rate is doubled. Treatment rates of neoadjuvant therapy with 4 Gy radiation at $48 \mathrm{~h}$ for the 75,100 , and $200 \mu \mathrm{M}$ doses of Docetaxel were 1.64, 1.71, and 1.85, respectively. However, treatment rates for neoadjuvant therapy with 2 Gy radiation at all doses of Docetaxel were about 1 , reconfirming the minimal effects of neoadjuvant therapy at this dose of radiation.

\section{Conclusions}

In this paper the synergistic effect of Docetaxel and ionization radiation was investigated as a new approach in cancer treatment. To this end, Docetaxel was characterized followed by his exposure with different concentrations to MCF-7 cell line. Then cells were treated by ionization radiation and their viability was monitored at 24, 48 and $72 \mathrm{~h}$ after this treatment. It was revealed that, compared with monotherapy, neoadjuvant therapy, is more effective in damaging and killing cancer cells. For clinical purposes, the optimum doses of radiation and Docetaxel should be determined by weighing the side effects of these modalities against their benefits. Certainly, further in vitro, in vivo and clinical trial studies are needed to identify the optimum doses of Docetaxel and radiation for treating breast cancer. Study findings suggest that neoadjuvant therapy by using Docetaxel and 4 and 6 Gy ionizing radiation has synergistic effects on MCF-7 cell death and produces more significant results compared with monotherapy modalities.

\section{Acknowledgements}

Not applicable.

Funding

There was no funding source for this study.

Availability of data and materials

Please contact corresponding author for data requests.

Authors' contributions

MBT carried out the design and coordinated the study, participated in most of the experiments and prepared the manuscript. AEF provided assistance in the design of the study, coordinated and carried out all the experiments and participated in manuscript preparation. HS and HE provided assistance for some experiments. All authors have read and approved the content of the manuscript.

Ethics approval and consent to participate Not applicable. 


\section{Consent for publication}

Not applicable.

\section{Competing interests}

The authors declare that they have no competing interests.

\section{Publisher's Note}

Springer Nature remains neutral with regard to jurisdictional claims in published maps and institutional affiliations.

\section{Author details}

${ }^{1}$ Medical Physics and Medical Engineering Department, School of Medicine, Isfahan University of Medical Sciences, Isfahan 8175, Iran. ${ }^{2}$ Anatomy Department, School of Medicine, Isfahan University of Medical Sciences, Isfahan, Iran. ${ }^{3}$ Radiation \& Oncology Department, School of Medicine, Isfahan University of Medical Sciences, Isfahan, Iran.

Received: 14 April 2017 Accepted: 25 June 2017

Published online: 06 September 2017

\section{References}

1. Akbari A, Razzaghi Z, Homaee F, Khayamzadeh M, Movahedi M, Akbari ME. Parity and breastfeeding are preventive measures against breast cancer in Iranian women. Breast Cancer. 2011;18(1):51-5.

2. Huo D, Adebamowo C, Ogundiran T, Akang E, Campbell O, Adenipekun A, Cummings S, Fackenthal J, Ademuyiwa F, Ahsan H. Parity and breastfeeding are protective against breast cancer in Nigerian women. Br J Cancer. 2008; 98(5):992-6.

3. Loibl S, Denkert C, von Minckwitz G. Neoadjuvant treatment of breast cancer-clinical and research perspective. Breast. 2015;24:S73-7.

4. Liu B, Staren ED, Iwamura T, Appert HE, Howard JM. Mechanisms of taxotere-related drug resistance in pancreatic carcinoma. J Surg Res. 2001; 99(2):179-86.

5. Nogales E, Wolf SG, Downing KH. Structure of the aß tubulin dimer by electron crystallography. Nature. 1998;391(6663):199-203.

6. Demons M, Leahy M, Valle J, Jayson G, Ranson M, Hayes S, Howell A. Review of recent trials of chemotherapy for advanced breast cancer: studies excluding taxanes. Eur J Cancer. 1997;33(13):2171-82.

7. Qi C, Zhu YJ, Zhao XY, Lu BQ, Tang QL, Zhao J, Chen F. Highly stable amorphous calcium phosphate porous Nanospheres: microwave-assisted rapid synthesis using ATP as phosphorus source and stabilizer, and their application in anticancer drug delivery. Chem Eur J. 2013;19(3):981-7.

8. Yvon A-MC, Wadsworth P, Jordan MA. Taxol suppresses dynamics of individual microtubules in living human tumor cells. Mol Biol Cell. 1999; 10(4):947-59.

9. McGrogan BT, Gilmartin B, Carney DN, McCann A. Taxanes, microtubules and chemoresistant breast cancer. Biochimica et Biophysica Acta (BBA)-Reviews on Cancer. 2008;1785(2):96-132.

10. Kumar N. Taxol-induced polymerization of purified tubulin. Mechanism of action. J Biol Chem. 1981;256(20):10435-41.

11. Eniu A, Palmieri FM, Perez EA. Weekly administration of docetaxel and paclitaxel in metastatic or advanced breast cancer. Oncologist. 2005;10(9): 665-85.

12. Hernández-Vargas H, Palacios J, Moreno-Bueno G. Molecular profiling of docetaxel cytotoxicity in breast cancer cells: uncoupling of aberrant mitosis and apoptosis. Oncogene. 2007;26(20):2902-13.

13. Clarke SJ, Rivory LP. Clinical pharmacokinetics of docetaxel. Clin Pharmacokinet. 1999;36(2):99-114.

14. Wilson $L$, Jordan MA. Microtubule dynamics: taking aim at a moving target. Chem Biol. 1995;2(9):569-73.

15. Crown J. Docetaxel: overview of an active drug for breast cancer. Oncologist. 2001;6(Supplement 3):1-4.

16. Tishler RB, Norris CM, Colevas AD, Lamb CC, Karp D, Busse PM, Nixon A, Frankenthaler R, Lake-Willcutt B, Costello R. A phase I/II trial of concurrent docetaxel and radiation after induction chemotherapy in patients with poor prognosis squamous cell carcinoma of the head and neck. Cancer. 2002; 95(7):1472-81

17. Calais G, Bardet E, Sire C, Alfonsi M, Bourhis J, Rhein B, Tortochaux J, Man YTK, Auvray H, Garaud P. Radiotherapy with concomitant weekly docetaxel for stages III/IV oropharynx carcinoma. Results of the 98-02 GORTEC phase II trial. Int J Radiat Oncol Biol Phys. 2004;58(1):161-6.
18. Colevas AD, Busse PM, Norris CM, Fried M, Tishler RB, Poulin M, Fabian RL, Fitzgerald T, Dreyfuss A, Peters ES. Induction chemotherapy with docetaxel, cisplatin, fluorouracil, and leucovorin for squamous cell carcinoma of the head and neck: a phase I/II trial. J Clin Oncol. 1998;16(4):1331-9.

19. Mose S, Böttcher HD, Bitter K. Multimodality treatment including postoperative radiation and concurrent chemotherapy with weekly docetaxel is feasible and effective in patients with oral and oropharyngeal cancer. Strahlenther Onkol. 2005;181(1):26-34.

20. Vermorken JB, Remenar E, Van Herpen C, Gorlia T, Mesia R, Degardin M, Stewart JS, Jelic S, Betka J, Preiss JH. Cisplatin, fluorouracil, and docetaxel in unresectable head and neck cancer. N Engl J Med. 2007; 357(17):1695-704

21. Steel G, McMillan T, Peacock J. The radiobiology of human cells and tissues. In vitro radiosensitivity. The picture has changed in the 1980s. Int J Radiat Biol. 1989:56(5):525-37.

22. Desouky O, Ding N, Zhou G. Targeted and non-targeted effects of ionizing radiation. Journal of Radiation Research and Applied Sciences. 2015;8(2):247-54.

23. Herskovic A, Martz K, Al-Sarraf M, Leichman L, Brindle J, Vaitkevicius V, Cooper J, Byhardt R, Davis L, Emami B. Combined chemotherapy and radiotherapy compared with radiotherapy alone in patients with cancer of the esophagus. N Engl J Med. 1992;326(24):1593-8.

24. Choy H, Rodriguez F, Koester S, Hilsenbeck S, Von Hoff DD. Synergistic effects of Taxol/Taxotere on radiation sensitivity on human tumor cell lines. Int J Radiat Oncol Biol Phys. 1992;24:274.

25. Hennequin C, Giocanti N, Favaudon V. Interaction of ionizing radiation with paclitaxel (Taxol) and docetaxel (Taxotere) in HeLa and SQ20B cells. Cancer Res. 1996;56(8):1842-50

26. Dreyfuss Al, Clark JR, Norris CM, Rossi RM, Lucarini JW, Busse PM, Poulin MD Thornhill L, Costello R, Posner MR. Docetaxel: an active drug for squamous cell carcinoma of the head and neck. J Clin Oncol. 1996;14(5):1672-8.

27. Matsuura M, Hasegawa M, Hayakawa K, Kawashima M, Nasu S, Nakamura $Y$, Mitsuhashi N, Niibe $H$. Experimental study of the effects on apoptosis of docetaxel alone and in combination with irradiation. Oncol Rep. 2000;7(2):289-382.

28. Pradier O, Rave-Fränk M, Lehmann J, Lücke E, Boghun O, Hess CF, Schmidberger $\mathrm{H}$. Effects of docetaxel in combination with radiation on human head and neck cancer cells (ZMK-1) and cervical squamous cell carcinoma cells (CaSki). Int J Cancer. 2001;91(6):840-5.

29. Shigematsu N, Kawata T, Ihara N, Kawaguchi O, Kutsuki S, Ishibashi R, Kubo A, Ito $\mathrm{H}$. Effect of combined treatment with radiation and low dose etoposide on cell survival. Anticancer Res. 2000;21(1A):325-8.

30. Kars M, Iseri Ö, Ural A, Avcu F, Beyzadeoglu M, Dirican B, Gündüz U. Development of radioresistance in drug resistant human MCF-7 breast cancer cells. J Radiother Pract. 2009;8(4):207-13. doi:10.1017/ S1460396909990070

31. Chou T-C, Talalay P. Quantitative analysis of dose-effect relationships: the combined effects of multiple drugs or enzyme inhibitors. Adv Enzym Regul. 1984;22:27-55.

32. Leonard CE, Chan DC, Chou T, Kumar R, Bunn PA. Paclitaxel enhances in vitro radiosensitivity of squamous carcinoma cell lines of the head and neck Cancer Res. 1996;56(22):5198-204.

33. Ural AU, Avcu F, Candir M, Guden M, Ozcan MA. In vitro synergistic cytoreductive effects of zoledronic acid and radiation on breast cancer cells. Breast Cancer Res. 2006;8(4):R52.

34. Chou TC. The median effect principal and the combination index for quantitation of synergism and antagonism. Synergism Antagonism Chemother. 1991:61-102.

35. Balkman CE, Gieger TL, Zgola MM, Lewis LD, MC ME. In vitro characterization of Docetaxel as a radiosensitizer in canine and feline cancer cell lines. Open Journal of Veterinary Medicine. 2012;2(04):285.

36. Steel GG, Peckham MJ. Exploitable mechanisms in combined radiotherapychemotherapy: the concept of additivity. Int J Radiat Oncol Biol Phys. 1979; 5(1):85-91.

37. Le Chevalier T, Arriagada R, Quoix E, Ruffle P, Martin M, Tarayre M, MarieJosé L-T, Douillard J-Y, Laplanche A. Radiotherapy alone versus combined chemotherapy and radiotherapy in nonresectable non-small-cell lung cancer: first analysis of a randomized trial in 353 patients. J Natl Cancer Inst. 1991;83(6):417-23

38. Milas L. Docetaxel/radiation combinations: rationale and preclinical findings. Clinical lung cancer. 2002;3:S29-36. 
39. Tabuchi S, Ozawa S, Koyanagi K, Shigematsu N, Kubo A, Ueda M, Kitagawa Y, Kitajima M. Radiation-sensitizing effect of low-concentration docetaxel on human esophageal squamous cell carcinoma cell lines. Experimental and therapeutic medicine. 2011;2(4):601-6.

40. Wardman P. The importance of radiation chemistry to radiation and free radical biology (The 2008 Silvanus Thompson Memorial Lecture). Br J Radiol. 2009;82(974):89-104

41. Dole $\mathrm{M}$, ed. The radiation chemistry of macromolecules, vol. 2. Elsevier; 2013. https://scholar.google.com/scholar?q=The+radiation+chemistry+of + macromolecules\&btnG $=\& h 1=e n \& a s \_s d t=0 \% 2 C 5$

Submit your next manuscript to BioMed Central and we will help you at every step:

- We accept pre-submission inquiries

- Our selector tool helps you to find the most relevant journal

- We provide round the clock customer support

- Convenient online submission

- Thorough peer review

- Inclusion in PubMed and all major indexing services

- Maximum visibility for your research

Submit your manuscript at www.biomedcentral.com/submit
Biomed Central 